\title{
The Effect of Reinsurance on the
}

\section{Development of Insurance Industry and the}

\section{Nigeria Economy}

\author{
Author: Kayode Ogunlami \\ Department of Insurance \\ School of Management and Business Studies \\ Lagos State Polytechnic, Ikorodu.
}

$+2348023450306$

DOI: 10.26821/IJSRC.9.5.2021.9506

\begin{abstract}
The continuous decline and collapse of insurance companies due to poor management of risk and their inability to reinsure appropriately significantly affects the growth of insurance companies and the economy of the nation at large. This paper hereby examines the effect of reinsurance on the development of insurance industry and the Nigeria economy. The objectives of this paper are to determine the effect of reinsurance on the performance of Insurance companies; and to ascertain the effect of reinsurance on the growth of the Nigerian economy. The research method and design adopted for this research work is the expo facto research design method which involves collecting financial records of the insurance companies listed on the Nigerian Stock Exchange and documenting their past financial activities including total value of re-insurance fund, and profitability. Data relating the Nigeria economy (GDP) was equally solicited from the Nigerian Stock Exchange (NSE). This study revealed that: reinsurance has significant effect on performance of Insurance companies; and reinsurance has significant effect on the growth of the Nigerian economy. This paper recommended that insurance companies in Nigeria should put proper reinsurance programs into priority, and insurance companies diversify their investment portfolios and embrace effectively, reinsurance cover for their businesses in order to diversity their risk; also, appropriate effort on the part of the regulatory bodies and stakeholders in the industry should be put in place that will ensure effective underwriting and claims management practices within the industry.
\end{abstract}

Keywords: Development, Insurance Industry, Reinsurance, Nigeria Economy

\section{Introduction}

The development of insurance industry around the world has been a matter of concern among researchers. In today's complex and catastrophe-plagued business environment, the judicious use of risk mitigation strategies in insurance and reinsurance in particular, is vital to the sustainable financial viability of insurance 
corporations(Taylor, Bisira, \& Farinde, 2019). Being essentially insurance purchased by an insurer from a reinsurer, reinsurance has served as a time-honored risk management activity on which an insurer can capitalize to achieve manifold mutually complementary business objectives. From a risk management perspective, reinsurance provides a powerful tool for an insurer to stabilize its risk exposure by ceding unbearable catastrophic losses to a reinsurer, which is generally more geographically diversified than an insurer. As a result, the amount of risk and the present formal increase in the capital requirement faced by the insurer can be maintained at a level that the insurer consider appropriate. Meanwhile, reinsurance bolsters the underwriting capacity of the insurer and, in turn, empowers the insurer to assume losses from its policyholders that it is otherwise incapable of underwriting (Ambrose, 2020).

Risks have ever been present since the existence of man and if not properly mitigated may lead to disruption of lives, property, earnings and businesses. The dynamism associated with the concept of risk has many disciplines like economics, finance; accounting, mathematics, statistics, business management and the like define it with no consensus. Interestingly, from insurance perspective, there seems to be no convergent view among scholars as to what constitutes risk (Olufemi, 2019). He furthers state that, despite this divergent view, common feature shared by the authors is that exposure to risk is created whenever an act gives rise to possibility of loss (Banjo, 2019).

However, Bressan (2020) asserts that,one of the main reasons why insurance companies purchase reinsurance coverage is always to protect themselves against the risks of losses above certain thresholds which can sometimes be catastrophic. Although reinsurance is a major risk and capital management tool available to insurers, it seems to be hardly known outside the insurance sectorlike banking, and some other financial industry sectors. The empirical evidence seen so far suggests that the purchase of reinsurance introduces substantial changes to several characteristics of insurers, besides their risk profile.Like, the study carried out by Dansu and Obalola (2018), they are of the opinion that, to analyze the effect on both profit and losses and capital requirement of alternative reinsurance strategies or programs, that,two classical proportional and nonproportional treaties were introduced by extending classical relations, where they derive moments of combined ratios by considering both the cases of Quota-Share proportional treaty (QS) and Excess of Loss (XL) treaties. According to the Quota-Share, they analytically describe how alternative methodologies to identify ceding commissions have an effect on the moments of the probability distribution of combined ratios and on the capital requirements for Premium Risk. Indeed, in the management practice, the insurer must usually choose among different efficient reinsurance strategies, taking into account either profitability sacrifice or capital saving (Aduloju \& Ajemunigbohun, 2017).

They also carried out a case study based on two different multi-line Non-Life insurers allows the comparison of the effect of wide strategies on both profitability and allocated capital, which makes them to be able to come up with the conclusion that, different reinsurance coversprovided by the real market makes the insurance companies able to identify the most appropriate strategic planning which can help serve as a very key tool to enhance their growth and development.Also, Augustine and Lukmon (2019) in their study carried out on reinsurance and the performance of the ceding company, they are of the conclusion that, there is a strong positive relationship between reinsurance capacity and gross written premium of insurance companies in Nigeria. Reinsurance provides an insurance company with capacity to compete against other insurance companies in a market where size would be a significant virtue, they further assert that, Reinsurance provides an insurance company with capacity to compete against other insurance companies in a market where size would 
be a significant virtue. The size of a company is an attraction to insurance intermediaries in placing their clients' insurance business.

The development of Insurance and reinsurance has been slow over the years compared to other financial sectors in Nigeria.This is one of the problem Nigerian insurance industries has been facing, as a result of the previous past experience they have been facing with the insuring public (Insured) based on the high number of claimratio, usually arising from the lack of proper underwriting procedures from some insurers and not having adequate reinsurance programs to protect them against any kind of loss that might be catastrophic in nature or large amount of claim which usually leads to the liquidation of most insurance in the past.

According to Gian, Nino, Savelli, Diego, and Zappa (2020), he said that, even with the existence of reinsurance in Nigeria, most of the profitable insurance businesses from the multinational companies in Nigeria, the percentage of the risks that are being retained by the whole of the Nigerian insurance companies are not up to $10 \%$.

\section{Objectives of the Study}

1. To determine the effect of reinsurance on the performance of Insurance companies.

2. To ascertain the effect of reinsurance on the growth of the Nigerian economy

\section{Literature Review}

\section{Reinsurance}

Dansu and Obalola (2018) investigate "the effect of ceded reinsurance on the solvency of primary insurers". The study is hinged on the fact that less solvent insurer tends to use more reinsurance because of its inability to raise needed capital in the financial market. Nine hundred and eighty (980) property and liability insurance companies were involved in the study. The study reveals that utilization of reinsurance could be an indicator that exposes the insurer's risk. In a related study, Gian, Nino, Savelli, Diego, and Zappa (2020) investigated corporate demand for reinsurance. The aim of the study is to examine the state of the international reinsurance market on the demand for reinsurance by property and casualty insurance companies in United States of America. Findings from the study reveal that an insurer with higher profits tends to depend less on reinsurance because they have higher capacity to weather financial pressures. Furthermore, Olufemi (2019) carry out similar study in Taiwan. In their study, they examine the determinants of insurer retentions for property-liability insurance companies in the Taiwan insurance industry. Findings from the study share the same view with Aduloju and Ajemunigbohun (2017) which assert that insurance companies that are more profitable are in a better position to absorb large unexpected losses and therefore be less affected by the under-investment problem. Augustine and Lukmon (2019) embark on a study titled "interactions between risk taking, capital and reinsurance for property and liability insurance firms". Objective the authors aimed to achieve from the study is to analyze capitalization policy and its relationship to risk-taking. The result is consistent with their theoretical hypotheses and further highlights the existence of significant relationship between the key variables (risk-taking, capital and reinsurance) and supporting the view that they are jointly determined. Ambrose (2020) carried out a 
Volume 9 Issue 5 May 2021

study on reinsurance analysis with respect to its impact on the performance of non-life insurance companies in Pakistan. The article examines whether reinsurance practice positively affects the performance of non-life insurers in Pakistan or conversely has any negative effect on them. They opine that whether insurers are financially stable or unstable, they should try to reduce their dependence and exposure on reinsurance because the increased reliance exposes them to the potential risk of declined performance. A more explicit and interesting study that shows the interaction between reinsurance utilization and performance of insurance companies is that of Iqbal, Rehman and Shahzad.(2014). The study titled "analysis of change in profitability due to reinsurance utilization and leverage levels of non-life insurance sector of Pakistan" is to examine the relationship between profitability reinsurance and leverage level of private sector non-life insurers in Pakistan. The study indicates that increased dependence on reinsurance arrangement will decrease profitability as leverage level has a significant negative impact on the profitability. They further suggest that for insurance companies to increase their underwriting capacity and stabilize their earnings, they must depend less on reinsurance.

\section{Economic Importance of Reinsurance to Insurance Companies}

Reinsurance is an economic instrument used by insurance companies to further improve their risk spreading exercise. This means that the buying of reinsurance is very paramount to insurance companies. Dansu and Obalola (2018) in their study express that, the purchase of reinsurance has also been identified as one of the vital links in the sustainability of micro-insurance schemes in times of environmental disasters and economic shocks. This implies that reinsurance invariably holds sustainability pillars of any national economy. The main motivation for purchasing insurance or reinsurance is risk sharing, but there are many evidences that advocate that optimal risk sharing is not the only motive for using reinsurance (Umit \& Hasan, 2014). In line with this, Sadhak (2015) contented that, the purchase of reinsurance by primary insurance carriers could also help to mitigate the underinvestment problem which arises due to the agency cost of debt, as well as the expected bankruptcy costs, thus contributing to sustainable profitability. Reinsurance has a global feature as manifested by economic interdependency, mobility of capital and transactions across borders, sharing regulations, international competition and management; and like any product, it is subject to cycles and fluctuations driven by internal and external factors (Plantin, 2006).Therefore, purchase of reinsurance cover by insurance companies will help minimize drastically, the fluctuations in the income of insurance companies, which may automatically leads to reduction in their expected loss and increase their risk appetite.Ozuomba, Onyemaechi, and Ikpeazu, (2017) in their study believed that reinsurance assists in reducing the unnecessary volatility or instability in the financial statements, particularly profit and loss statement. According to the authors, this reduction in the volatility helps the insurance companies to create sustainable shareholder's value. This implies that reinsurance is a promotional tool for the effectiveness and sustainability of insurance companies in their business operations. Jack (2021)highlights the importance of reinsurance in reducing the expected costs of bankruptcy induced at high leverage. And it is evident that, the insurance companies, because of the nature of their business, which is based on risk management and its coverage, usually have high probability of increased volatility in their cash flows and purchase reinsurance so that the risk of bankruptcy and the expected bankruptcy cost can be reduced Umit and Hasan (2014). This means that reinsurance serves as the economic risk management tool that cushions the effect of the risks that overwhelm the business operating capacity insurance companies. Okonkwo and Okeke (2019) contented that the use of reinsurance reduces the effects of 
Volume 9 Issue 5 May 2021

large unexpected losses and increases the probability the insurer would benefit from investment in tax-favored assets. The aim of contract of reinsurance is to indemnify the primary insurance companies against loss or any liability relating to the risk associated with insurance business, and prevents them from being insolvent to their insuring customers. Chi-Chuan, Chien-Chiang, and Donald (2020) finds that insurers with a higher level of leverage tend to reinsure to reduce the probability of insolvency and mitigate the agency costs arising from the conflicts between policyholders and shareholder-owners. This implies that any insurance company with much leverage should optimally embrace the use of reinsurance passionately. Reinsurance helps protect insurers against unforeseen or extraordinary losses by allowing them to spread their risks. For example, a catastrophic fire at an industrial enterprise could financially devastate its insurer (Marijuana, Sandra, \& lime, 2019). Reinsurance provides insurance companies with the ability to mitigate the impact of unexpected major losses, to ensure stability of earnings, and to increase underwriting capacities (Laz \& Omokiniovo, 2015). Therefore, a better reinsurance decision can create value for insurance companies, in order to brace for any potential financial crisis (Kugler \& Ofoghi, 2012).

\section{Reinsurance and Insurance Company Performance}

Marijuana, Sandra and lime (2019)reinsurance activities may increase cost, leading to higher prices and/or lower profits. According to Laz and Omokiniovo (2015), reinsurance transactions are related to underwriting risk and capacity, and affect ceding insurers' performance and conduct. In line with this, Rose (2019) expressed that the reinsurance literature has suggested that firms that are more profitable should be better able to absorb large unexpected losses and therefore use less reinsurance. Reinsurance transactions are related to underwriting risk and capacity, and affect ceding insurers' performance and corporate growth (Laz \& Omokiniovo, 2015). Thus, the buying of reinsurance is important to the performance of insurance companies. A better reinsurance decision can create value for insurance companies, in order to brace for any potential financial crisis (Laz \& Omokiniovo, 2015). Sule and Momoh (2019) opined that the purchase of reinsurance can reduce the volatility of pre-tax income, which results in reduced expected tax liability of the company. Reinsurance is an integral part of the insurance market and plays the vital role regarding the financial stability of the global insurance markets (Umit \& Hasan, 2014).

Reinsurance activities may increase cost, leading to higher prices and/or lower profits, thus, reinsurance transactions are related to underwriting risk and capacity, and affect ceding insurers' performance and conduct (Laz \& Omokiniovo, 2015). Goran, Ilija, and Vladimir (2010)assert that, the practice of reinsurance primarily shares the risk of direct insurer and provides several benefits by way of providing advices and services based on its expertise knowledge and specialized skills in the field. According to the author, it provides monetary benefits by way of providing incentives for investment, by optimal sharing of risk, by reducing financial distress and bankruptcy cost, by reducing volatilities in cash flows and by increasing capital and capacity to write more business. Reinsurance transactions are related to underwriting risk and capacity, and affect ceding insurers' performance and corporate growth (Bressan, 2020).

Goran, Ilija, and Vladimir (2010) asserts that it is the reinsurance which lowers the risk carried by primary insurance companies. Reinsurance includes various forms such as facultative, financial, non-proportional, 
proportional, quota share, surplus, and treaty reinsurance. Reinsurance is an advance step in the risk-spreading exercise. Insurance companies, which assume the risk of loss from their policyholders, advance the spread of the risk of loss to reinsurance companies by entering into reinsurance agreement some of the premiums the insurance company collects from its policyholders are essentially paid to the reinsurance companies as the premiums for the insurance companies' purchase of a reinsurance contract. Reinsurers set their premiums by also looking at the historical loss picture of the insurance company and the types of losses typically generated by the policies issued by that primary insurance company. When put together, both insurance and reinsurance help spread the risk of loss among a wide group of companies, which helps to mitigate the potentially financially destructive effect of over-accumulation of risk.

\section{Underwriting Assistance}

Reinsurers can provide the technical expertise needed by cedants to enter new lines of business in areas that the underwriters are not familiar with through their various books. This helps Cedants to broaden their book of business and expand their underwriting opportunities. Sule and Momoh (2019) assert that reinsurance allow primary insurers to boost the underwriting revenue more than what would otherwise be possible. As a result, insurance companies would be more competitive in the insurance market as they have been empowered in their underwriting aspect.

\section{Capacity}

Reinsurance in place allows the cedants to underwritelarger amounts of insurancerisks. This helps solve problems imbalance accounts of insurance companies. Sadhak (2015) expresses that Insurance companies can only accept risks up to a certain limit based on authorized assets (capital and solvency margin). Therefore, the primary object of reinsurance is to protect the primary insurer or the ceding company from being crippled by large losses beyond its financial capacity (Bressan, 2020). Marijuana, Sandra, and lime (2019) affirms reinsurance broadens the economic capacity of the insurer by both distributing the portfolio of risks (just as the original policy broadens the capacity of the insured for more businesses and projects) and byway of creating the capacity to expand the market share and investment options, competitive and retain liquidity for acceptance of additional and large risks. The author affirmed that without it, insurers may use Coinsurance which shares direct responsibility for the risk.

\section{Financial}

Reinsurance relieves the pressure on the cedant's surplus during speedy premium growth. Global reinsurers offer further advantages to local insurance companies, national governments and public-sector bodies when planning for future financial commitments, whether related to disaster relief or not (Umit \& Hasan, 2014). Capital provided under a reinsurance payout is an external source to the local economy: it is not redistribution but an injection, helping to stabilize the financial situation in the wake of an economic shock (Okonkwo \& Okeke, 2019). As a result, the cedant's premium to surplus ratio is reduced and there is enhanced ability and willingness on the part of the cedant to write business. 


\section{Stabilization}

Reinsurance helps the insurance companies smooth their overall operating results generated by economic, social and natural forces from year to year. It protects the cedant's capital and surplus needed for growth as well as a cedant's customers, shareholders and to some extent its employees. Reinsurers help the primary insurers by way of stabilization or smoothing of losses and Portfolio or entire range of risks management (Kugler \& Ofoghi, 2012).

\section{Marketing Tool}

Reinsurance expands the ability of insurance companies to assume more risks. This in turn, enhances the image of insurance companies as a broad-based market and responsive insurers can have confidence when in an unfamiliar coverage area of their business. Reinsurance companies provide expertise and experience in pricing and developing of new insurance products that can affect the purchase of reinsurance (Aduloju \& Ajemunigbohun, 2017).

\section{Catastrophe Control}

Reinsurance affords protection against catastrophic losses in which multiple insured can be involved in one occurrence. Every economy is expose and prone to the risk of natural disasters, disruptive technologies, political turmoil, terrorist attacks, and environmental degradation. These mentioned risks are just a few of the inherently unpredictable risks that can inflict heavy shocks on individuals, Organizations, regions, and societies at large. In a developed economy, such shocks can become more complex in their forms, more sudden in their impact, and severely in their consequences. The United Nations Office for Disaster Risk Reduction considered a disaster as "a serious disruption of the functioning of a community or a society involving widespread human, material, economic or environmental losses and impacts, which exceeds the ability of the affected community or society to cope using its own resources" (Ambrose, 2020). Reinsurance protects the cedant against a single catastrophic loss or multiple large losses. Therefore re/insurance and other prepaid risk-financing mechanisms form a critical part of a comprehensive disaster risk management strategy (Goran, Ilija, \& Vladimir, 2010).

Goran, Ilija, \& Vladimir (2010)opined that reinsurance can substitute capital for improving the solvency of insurance companies. And also, insurers are more prone to supplying reinsurance to other firms as they receive growing amounts of reinsurance for their own.

Ambrose (2020) opined that the presence of the reinsurer's default risk diminishes the benefit of reinsurance to the insurer. Such a reduction in benefit needs to be taken into account when formulating the optimal insurancereinsurance strategies.

Sadhak (2015)asserts that a strong-based market for reinsurance activities allows for solvency of insurance companies particularly in the event of high severity losses such as hurricane and plane crashes.

Laz and Omokiniovo (2015)argue that reinsurance utilization may be beneficial to insurer but on the flip side, it may be expensive and result in insolvency of insurers. 
Umit and Hasan (2014)opine that reinsurers are at the pinnacle of insurance market environment, because the abilities of reinsurers may bring about financial unrest within the insurance industry, which could result in spillover effect in the entire economy.

Rose (2019)reveals that performance of insurance companies is vulnerable to dependence and exposure on reinsurance because it increases the loss ratio of insurance firms under review. The study opines that whether insurers are financially stable or not, they should reduce their exposure to reinsurance because it exposes them to the potential risk of declined performance.

\section{Research Methodology}

The research method and design adopted for this research work is the expo facto research design method which involves collecting financial records of the insurance companies listed on the Nigerian Stock Exchange and documenting their past financial activities including total value of re-insurance fund, and profitability. Data relating the Nigeria economy (GDP) was equally solicited from the Nigerian Stock Exchange (NSE).

\section{Method of Data Analysis}

In order to ascertain the effect of re-insurance on the performance of insurance company and the Nigerian economy at large, regression model was used to test the hypotheses of the study.

\begin{tabular}{|c|c|c|}
\hline \multicolumn{3}{|c|}{ Perf $=\alpha+\beta 1($ Re-Ins $)+$ e $\ldots 1$} \\
\hline \multicolumn{3}{|c|}{$\mathrm{GDP}=\alpha+\beta 1(\mathrm{Re}-\mathrm{Ins})+\mathrm{e} \ldots 2$} \\
\hline Perf & $=$ & Performance (Profitability \\
\hline GDP & $=$ & Gross Domestic Product \\
\hline Re-Ins & $=$ & Re-insurance \\
\hline$\alpha$ & $=$ & Intercepts \\
\hline$\beta$ & $=$ & Beta Value \\
\hline e & $=$ & Error Terms \\
\hline
\end{tabular}

\section{Data Analysis and Presentation}

Data(Aggregate Re-insurance funds) and the Gross Domestic Products (GDP) were solicited from the official records of the Nigerian Stock Exchange for a period of five (5) years (2016 - 2020). 


\section{Tests of Hypotheses}

\section{Hypothesis One}

$\mathrm{H}_{01}: \quad$ Reinsurance does not have significant effect on performance of Insurance companies

Table 1Model Summaryb for Hypothesis One

\begin{tabular}{lrrrrr}
\hline Model & R & R Square & Adjusted R Square & Estimate & Durbin-Watson \\
& & & & & \\
\hline 1 & $.721 \mathrm{a}$ & .677 & .525 & 85474100154.5 & 2.51
\end{tabular}
a. Predictors: (Constant), Reinsurance
b. Dependent Variable: Performance of Insurance companies

Source: SPSS version 25 output.

Table 2 Coefficientsa for Hypothesis One

\begin{tabular}{|c|c|c|c|c|c|}
\hline \multirow{3}{*}{ Model } & & & \multicolumn{3}{|l|}{ Standardized } \\
\hline & \multicolumn{2}{|c|}{ Unstandardized Coefficients } & \multirow{2}{*}{$\begin{array}{c}\text { Coefficients } \\
\text { Beta }\end{array}$} & \multirow{2}{*}{$\mathrm{t}$} & \multirow{2}{*}{ Sig. } \\
\hline & B & Std. Error & & & \\
\hline $1 \quad$ (Constant) & 541416329 & 41023109 & & 2.210 & .001 \\
\hline Reinsurance & 4.141 & $3 . \overline{210}$ & .671 & 3.21 & .009 \\
\hline
\end{tabular}

\section{Source: SPSS version 25 output.}

$\mathrm{R}$ Sqaure explain the relationship between variable. As shown in the model summary, there is positive relationship between Reinsurance and performance of Insurance companies, and this account for about $67 \%$. $\mathrm{R}$ being the determinant of correlation explain the extent to which the independent variable could explain the dependent variable. $\mathrm{R}$ square as shown in model summary is about $72 \%$, this implies that the independent variables can predict or determine dependent variables up to $72 \%$. This simply means that Reinsurance can determine changes in performance of Insurance companies up to about $72 \%$. This study revealed that a unit change in Reinsurance account for about 4.1 positive unit change in performance of Insurance companies. This study revealed that Reinsurance has significant effect on performance of Insurance companies. The p value of 0.009 is lower than 0.05 , we hereby conclude that Reinsurance has significant effect on performance of Insurance companies, and hereby reject the null hypothesis. 


\section{Hypothesis Two}

$\mathrm{H}_{02}$ : $\quad$ Reinsurance does not have significant effect on the growth of the Nigerian economy.

Table 3Model Summaryb for Hypothesis Two

\begin{tabular}{|c|c|c|c|c|c|}
\hline & & & & Std. Error of the & Durbin- \\
\hline Model & $\mathrm{R}$ & R Square & Adjusted R Square & Estimate & Watson \\
\hline 1 & $.518 \mathrm{a}$ & .47 & .495 & 77414100154.5414 & 1.51 \\
\hline
\end{tabular}
a. Predictors: (Constant), Reinsurance
b. Dependent Variable: Growth of the Nigerian economy

Source: SPSS version 25 output.

Table 4Coefficientsafor Hypothesis Two

\begin{tabular}{|c|c|c|c|c|c|}
\hline \multirow[b]{3}{*}{ Model } & \multicolumn{5}{|c|}{ Standardized } \\
\hline & \multicolumn{2}{|c|}{ Unstandardized Coefficients } & \multirow{2}{*}{$\frac{\text { Coefficients }}{\text { Beta }}$} & \multirow[b]{2}{*}{$\mathrm{t}$} & \multirow[b]{2}{*}{ Sig. } \\
\hline & B & Std. Error & & & \\
\hline 1 (Constant) & 641416329 & 41003109 & & 1.210 & .011 \\
\hline Reinsurance & 3.141 & 2.210 & .411 & 3.21 & .001 \\
\hline
\end{tabular}

a. Dependent Variable: Growth of the Nigerian economy

\section{Source: SPSS version 25 output.}

There is positive relationship between Reinsurance and growth of the Nigerian economy, and this account for about $47 \%$. R being the determinant of correlation explain the extent to which the independent variable could explain the dependent variable. $\mathrm{R}$ square as shown in model summary is about $51 \%$, this implies that the independent variables can predict or determine dependent variables up to $51 \%$. This simply means that Reinsurance can determine changes in growth of the Nigerian economy up to about $51 \%$.

This study revealed that a unit change in Reinsurance account for about 3.14 positive unit change in growth of the Nigerian economy. This study revealed that Reinsurance has significant effect on the growth of the Nigerian economy positively. The p value of 0.001 is lower than 0.05 , we hereby conclude that Reinsurance has significant effect on the growth of the Nigerian economy.

This study revealed that:

1. Reinsurance has significant effect on performance of Insurance companies; and

2. Reinsurance has significant effect on the growth of the Nigerian economy.

\section{Conclusion}

Reinsurance is fundamental to insurance companies' operations. Though, it is very vague because it is a secondary market for insurance risks, it is hardly known outside insurance sector. Reinsurance serves as a capital management tool available to insurance companies, at the same time; insurers substitute it for capital which may allow them hold less capital thereby increasing their insolvency probability. The central point of 
this argument is focused on the fact that reinsurance dependence might affect insurance companies' operations on the long run, may be costly, uneconomical, reduce insurer's efficiency and its inability of sufficient assets to meet its debts, and on the long run erodes the profitability of general insurance companies in Nigeria.

\section{Recommendations}

Based on the findings from this study, the recommendations under this section which could be of benefit to insurance companies, the regulatory body and the insuring public itself and these recommendations are as follows:

1. Insurance companies in Nigeria should increase insurance program, capital, size and clientele base. This may translate to increase in financial capacity, bottom line and experience large pool of homogeneous exposures which will make the outcome more predictable and on the long run demand less of reinsurance protection.

2. Insurance companies in Nigeria should put proper reinsurance programs into priority, taking into consideration characteristics of their underwriting documents and consideration factors such as past loss experience, size of risks and frequency of losses. It is important for insurance companies to have optimal retention levels in their risk diversification management basically to ensure favorable financial performance

3. Insurance companies diversify their investment portfolios and embrace effectively, reinsurance cover for their businesses in order to diversity their risk.

4. Appropriate effort on the part of the regulatory bodies and stakeholders in the industry should be put in place that will ensure effective underwriting and claims management practices within the industry.

\section{References}

Aduloju, S., \& Ajemunigbohun, S. (2017). Reinsurance and performance of the ceding companies: the Nigerian insurance industry experience. Economics and Business Journals, 22(14), 19 - 29.

Ambrose, L. (2020, April 28). How does reinsurance create value to an insurer? A cost-benefit analysis incorporating default risk? Retrieved from Risk Management: http//www.mdpi.com

Augustine, S., \& Lukmon, A. (2019). Evaluation of impact of reinsurance mechanism on insurance companies sustainability in Nigeria. International journal of research, innovations and sustainable development, $7(1), 20$ - 37.

Banjo, K. (2019). Principles and practice of insurance. Lagos: Dekinbam Ventures Limited, Mushin.

Bressan, S. (2020, April 30). The impact of reinsurance for insurance companies. Retrieved from RiskGovernance and Control: FinancialMarkets \& Institutions: http://doi.org/10.22495/rgcv8i4p3

Chi-Chuan, L., Chien-Chiang, L., \& Donald, L. (2020). Income inequality, globalization, and country risk: a cross-country analysis. Technological and Economic Development of Economy, 26(2), 379 - 404. 
Volume 9 Issue 5 May 2021

Dansu, F., \& Obalola, A. (2018). Reinsurance utilization and dependence on the financial performance of nonlife insurers: evidence from Nigeria. Studies and Scientific Researches, Economics Edition, 8(2), 277 301.

Gian, P., Nino, D., Savelli, F., Diego, J., \& Zappa, O. (2020, April 29). The impact of reinsurance strategies on capital requirements for premium risk in insurance. Retrieved from Risk Management: www.mdpi.com/journal/risks

Goran, B., Ilija, Ć., \& Vladimir, Đ. (2010). The impact of globalization on the insurance and reinsurance market of eastern Europe. SEE Journal, 12(7), 10 - 27.

Jack, D. (2021, April 23). The guardian. Retrieved from Technology: https://guardian.ng/news/why-twitter-isopening-african-office-in-ghana/

Kugler, M., \& Ofoghi, R. (2012). Does insurance promote economic growth? Evidence from the UK. Division of Economics, University of Southampton, UK, 7(5), 147 - 155.

Laz, E., \& Omokiniovo, H. (2015). Contemporary globalization and the rural economy in Nigeria. American International Journal of Social Science, 4(3), 14 - 24.

Marijuana, C., Sandra, L., \& lime, P. (2019). Insurance sector development and economic growth in transition countries. International Research Journal of Finance and Economy, 14(8), 34 - 47.

Okonkwo, I., \& Okeke, D. (2019). Developments and innovations in Nigerian insurance industry: 2010-2018. International Journal of Research in Business, Economics and Management, 3(1), 1 - 17.

Olufemi, A. A. (2019). Empirical analysis of reinsurance dependence on the profitability of general insurance business in Nigeria. Academic Journal of Economic Studies, 5(4), 24 - 37.

Ozuomba, C., Onyemaechi, U., \& Ikpeazu, N. (2017). Effect of globalization on Nigerian financial sector. International Journal of Management Excellence, 8(3), 17 - 22.

Rose, P. (2019). Money and capital market. Rexas business Journal of the CIIN, 15(4), 20 - 31.

Sadhak, H. (2015). Globalisation and life insurance. Bimaquest Journal, 4(2), 21 - 33.

Sule, O., \& Momoh, J. (2019). Capital market and the Nigeria industrial growth, financial system and economic growth. Abuja: A CBN publication.

Taylor, H., Bisira, D., \& Farinde, J. (2019). Effect of re-insurance on the economic growth. Journal of Entreprenuers, 7(3), 314 - 342.

Umit, A., \& Hasan, D. (2014). Globalization of financial institution: A competitive approach to finance and Banking. Springer International Publishing Switzerland, 10(5), 319 - 324. 